\title{
脳内出血に対する軟性鏡手術と硬性鏡手術の比較
}

\author{
中野 高広，大熊 洋揮
}

\section{Comparison of Fiberscopic Surgery with Rigid Endoscopic Surgery for Intracerebral Hemorrhage}

\author{
Takahiro NAKAno, M.D. and Hiroki OHKuma, M.D. \\ Department of Neurosurgery, Hirosaki University Graduate School of Medicine, Hirosaki, \\ Japan
}

\begin{abstract}
Summary: While a rigid-type endoscope has been used for the surgery of intracerebral hemorrhage, a flexible fiberscopie is more maneuverable. But flexible fiberscopic surgery for intracerebral hemorrhage is challenging in terms of visual resolution of the operative field. We compared the results of this new method with that of our conventional method using a rigid-type endoscope.

A flexible fiberscope with an outer diameter of 4.8-mm was inserted into hematoma cavity by free hands, or in some cases under CT-guided stereotaxy. An irrigation-suction system is used to facilitate aspiration of hematoma with hard clots. The problem of interference of the visual field with clots was solved by water irrigation of the endoscopic lens. The operation time was comparable to that of our past surgery using a rigid endoscope (58 $\mathrm{min}$ vs. $53 \mathrm{~min}$ ), and the mean removal rate of hematoma was also similar to that of the rigid endoscopic surgery ( $77 \%$ vs. $86 \%)$. Although the results of the flexible fiberscopic surgery were comparable to that of the rigid endoscopic surgery, effective hemostat instruments are unavailable. For this reason, we select this surgery only for patients in subacute stage in which hemostat process is completed.

This method is only in the developmental stage, and advances in instruments are necessary to establish it.
\end{abstract}

\author{
Key words: \\ - fiberscope \\ - intracerebral hemor- \\ rhage \\ - water irrigation
}

Surg Cereb Stroke (Jpn) 37: 100-103, 2009

\section{はじめに}

これまで発表されてきた脳内出血に対する手術治療と内 科的治療を比較した RCT の中で手術優位を証明しえたの が唯一Auerらによる内視鏡手術である ${ }^{1)}$. 当施設でも 1980 年代より脳内出血に対しいち早く内視鏡手術を開発 し, その有効性を発表してきた ${ }^{2) 3) 6)}$. 当初は解像度の点 から硬性鏡を採用していたが，本邦の神経内視鏡の分野で は軟性鏡の普及が特徴的でもあり, その機動性を生かした
脳内出血手術の可能性を展開すべく試みを開始している. そこで脳内出血に対してこれまで当施設で行ってきた硬性 鏡手術と新たに試行中の軟性鏡手術の比較を試みた。

\section{手術方法}

最初に，1980年代より脳内出血に対してわれわれが行 ってきた内視鏡手術は硬性鏡を用いた手術であった。これ は内視鏡自体がオリンパス社の協力の下作られており，そ れを駒井式定位装置に連動する内視鏡シースに装着し，

弘前大学医学部 脳神経外科(受稿日 2008.8.7) (脱稿日 2008.11.19)〔連絡先： T036-8562 青森県弘前市在府町 5 弘前大学医学部 脳神 経外科 中野高広] [Address correspondence: Takahiro NAKANO, M.D., Department of Neurosurgery, Hirosaki University Graduate School of Medicine, 5 Zaifu-cho, Hirosaki, Aomori 036-8562, Japan] 

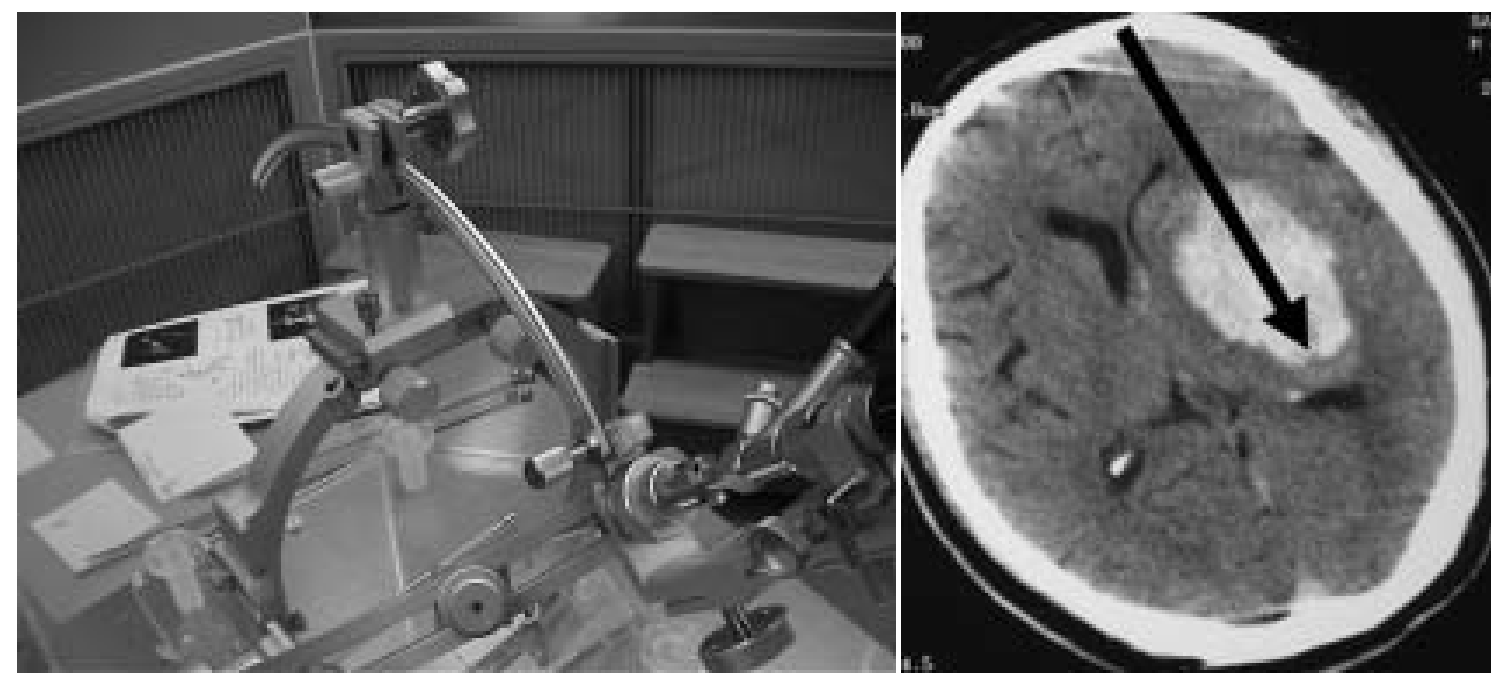

Fig. 1 A: The rigid endoscopic surgical system for intracerebral hemorrhage which had been used in our institution since 1980 's. B: Trajectory which endoscope is inserted into the hematoma cavity.

$\mathrm{A} \mid \mathrm{B}$

Table 1 Comparison between the rigid endoscopic surgery and the fiberscopic surgery

\begin{tabular}{lcccc}
\hline & N umber of the patients & M ean operation time & M ean removal rate \\
\hline Rigid endoscopic surgery & Total & 48 & & \\
& Putamen & 24 & 53 minutes & $86 \%$ \\
Thalamus & 15 & & \\
Lobar & 5 & \\
Cerebellum & 2 & 58 minutes & $77 \%$ \\
Fiberscopic surgery & 2 & & \\
& Pons & 6 & \\
\hline
\end{tabular}

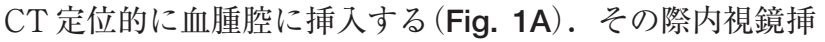
入は極力血腫の長軸方向に沿うように配虑する(Fig. 1B). この内視鏡システムはシースのワーキングチャンネルから 挿入された専用超音波吸引装置により硬い凝血塊を破砕, 吸引可能であった ${ }^{2) 3)}$ 。これに対し 2006 年よりわれわれが 試行している軟性鏡手術では内視鏡は NEU4L（株式会社 町田製作所)を使用している．軟性鏡の横にカテーテルを 取り付けてサクションプラス (ジョンソン・エンド・ジョ ンソン株式会社)で血腫をジェット水流で破砕しつつ吸引 する(Fig. 2A)，軟性鏡をシースなしで直接血腫腔内に挿 入することから，レンズを血液の付着から保護するため軟 性鏡先端にネラトンカテーテルを利用して作ったクリアチ ップを装着している．視野が血液で妨げられた場合，視野 を確保する目的でニューロジェットイリゲーター(ジョン ソン・エンド・ジョンソン株式会社)による水流を鈿子口 から流出させレンズ洗浄を行う(Fig. 2B)．止血デバイス として常にPAL-1 (エム・ディー・エム株式会社)を用意
して手術に臨んだが，これまで術中の出血は経験していな い.

結 果

Table 1 に硬性鏡手術と軟性鏡手術の手術結果を呈示す る。従来の CT 定位連動超音波吸引付き硬性鏡で手術した 48 例中, 被殼出血 24 例, 視床出血 15 例, 脳葉出血 5 例, 小脳出血 2 例，脳幹出血 2 例であった。これらに対する硬 性鏡手術の平均手術時間は 53 分であった。また平均摘出 率は $86 \%$ であった。それに対し，軟性鏡で手術した 6 例 はいずれも被殼出血で，平均手術時間 58 分であった。平 均摘出率は $77 \%$ であったが, 血腫が硬いものでは $50 \%$ と 摘出率は低かった。

\section{考察}

脳内出血の国際多施設 RCT である International STICH では手術適応か否か判断に迷うような脳内出血患者では, 

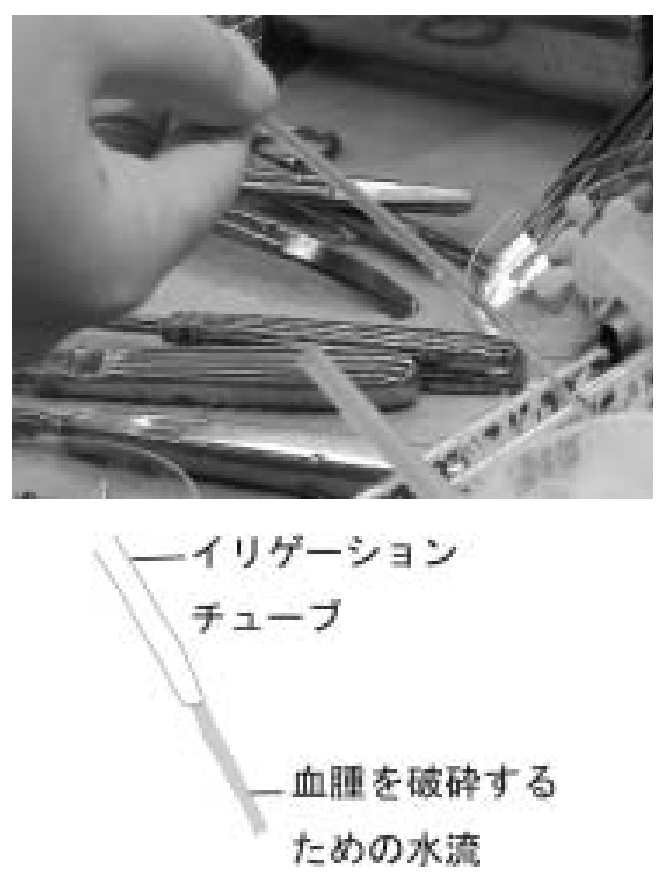

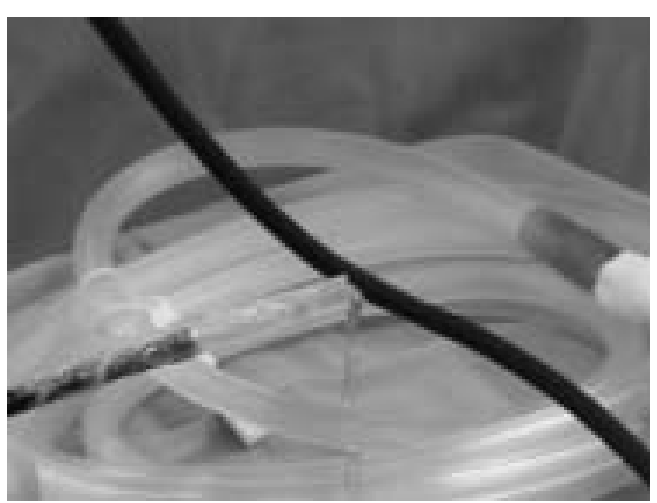

血液の付著からガードするチップ

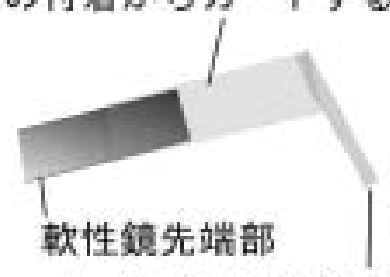

レンズ面を洗浄する水流

Fig. 2 A: Irrigation system is connected to the tube beside for making aspiration of hematoma easy by dissecting hard clot. B: An irrigation system connecting to a working channel of the fiberscope has a role to keep the lens clean. A tip of fiberscope is covered with a transparent cap made of silicon for purposes of guard from blood attachment to the lens.

早期手術の内科的治療に対する overall benefit は認められ ないという結果であった ${ }^{5)}$ 。一方そのログデータから集計 したところの，外科医が治療法を迷わない場合に手術を選 択した割合の国別のばらつきを比較した検討では国によっ てかなりの開きがみられ，日本では手術を選択する割合が 約 50\%で, 参加国の中ではちょうど中間の位置にあった ${ }^{4)}$. つまり現在わが国の中でも手術の優位性について脳外科医 の $50 \%$ は懐疑的ということであり, 手術が脳内出血の治 療の主役であった時代からすると隔世の感がある.しかし， 手術が神経症状の改善に有効なグループというのは確実に 存在するはずであり, われわれ外科医の努めは手術の精度 を上げ，より有効な治療法を開発していくことであろうと 思われる。そのような理念よりわれわれの施設では 1980 年代前半よりすでに脳内出血に対する内視鏡治療の開発を 行ってきた ${ }^{2) 37}$. 当初は解像度が高い理由で, 硬性鏡を 使用していた。硬性鏡は駒井式定位装置に連動させ, CT 定位的に血腫腔に挿入し, 超音波吸引装置により硬い凝血 塊を破砕，吸引する方法を行った。この手術は主に被款， 視床などの深部の出血が対象で, 手術時間 1 時間以内, 平 均摘出率 $85.5 \%$ と良好な結果を治めた。 ただシステムの構 成が複雑で易操作性に難点があったのと, 基本的に長軸に 沿った手術であるので縦型の血腫では有効な血腫吸引が可
能だが横径が長い血腫には不向きという短所があった。た とえば縦長の被殼出血では長軸方向にトラジェクトリーを とれば有効な血腫吸引が可能だが, 大きい血腫や形が複雑 な場合にはどうしても摘出率は下がってしまった。内視鏡 のこの問題に対する 1 つの解決法が国内で現在広く行われ ているクリアシースによる内視鏡手術であり，非常に理に かなったものであると考えられる ${ }^{8)}$ ももうひとつの解決法 としてわれわれは現在, 軟性鏡を用いる手術を試行してい る. その理由として軟性鏡は先端部がフレキシブルで血腫 腔内での移動が容易と考えられたことと, 操作の点で扱い やすく普及の上で有利と考えたことがあげられる，ただし 現時点では安全な止血法が確立していないことから，われ われにおける軟性鏡手術はクリアシースを用いる硬性鏡手 術とはコンセプトを異にしている.すなわち，クリアシー スを用いる硬性鏡手術は救命を目的とする急性期手術にお いて手術時間の短縮, 低侵襲性に有効であるのに対し, わ れわれの軟性鏡手術は現在のところ亜急性期に神経症状の 改善を目的に行っている. 脳内出血に対する内視鏡手術の 有効性は現在必ずしも確定しているとはいえないが，今後 臨床研究によって, 本治療の特徵である低侵襲性が転帰の 改善に結びつくようなサブグループを見つけ出すことは重 要である。 


\section{結}

語

脳内出血の治療において硬性鏡に比較して扱いやすい軟 性鏡によっても同様の効果が得られるものの，止血法など 改善すべき点がある。しかしいったんそれらの問題点をク リアできれば操作の簡便性など術者の負担軽減の点からも 有望な手術法であるともいえる。

\section{文献}

1) Auer LM, Deinsberger W, Niederkorn K, et al: Endoscopic surgery versus medical treatment for spontaneous intracerebral hematoma: a randomized study. J Neurosurg 70: 530-535, 1989

2）螧名国彦, 金奉均, 鈴木重晴, ほか：脳内血腫除去術に押 ける定位的脳手術用内視鏡システムの開発と臨床応用. 脳 卒中の外科 23: 109-115, 1995

3) Ebina K, Andoh A, Takahashi T, et al: Development and clinical usefulness of a new neuroendoscope system for CT-guided stereotactic brain surgery. Neurol Med Chir
(Tokyo) 30: 401-407, 1990

4) Gregson BA, Mendelow AD; STICH Investigators: International variations in surgical practice for spontaneous intracerebral hemorrhage. Stroke 34: 2593-2597, 2003

5) Mendelow $\mathrm{AD}$, Gregson BA, Fernandes HM, et al: Early surgery versus initial conservative treatment in patients with spontaneous supratentorial intracerebral haematomas in the International Surgical Trial in Intracerebral Haemorrhage (STICH): a randomised trial. Lancet 365: 387-397, 2005

6) Nakano T, Ohkuma H, Ebina K, et al: Neuroendoscopic surgery for intracerebral haemorrhage--Comparison with traditional therapies. Minim Invasive Neurosurg 46: 278283, 2003

7) Nakano T, Ohkuma H: Surgery versus conservative treatment for intracerebral haemorrhage--is there an end to the long controversy? Lancet 365: 361-362, 2005

8) Nishihara T, Teraoka A, Morita A, et al: A transparent sheath for endoscopic surgery and its application in surgical evacuation of spontaneous intracerebral haematomas. Technical note. J Neurosurg 92: 1053-1055, 2000 